Medika Kartika : Jurnal Kedokteran dan Kesehatan

ARTIKEL PENELITIAN

\title{
SUPLEMENTASI ZINK TIGA BULAN BERPENGARUH TERHADAP TINGGI BADAN BALITA STUNTING DI PUSKESMAS CILONGOK BANYUMAS INDONESIA
} (THREE MONTHS ZINC SUPPLEMENTATION INFLUENCES ON CHANGES IN

\section{HEIGHT AT THE CHILDREN WITH STUNTING AT THE COMMUNITY HEALTH CENTER IN CILONGOK BANYUMAS INDONESIA)}

\author{
$\underline{\text { Jihan Amalia }}^{1^{*}}$, Sri Quintina Indriyana ${ }^{2}$, Rissa Anggita Putri ${ }^{1}$ \\ ${ }^{1}$ Bagian Gizi Fakultas Kedokteran Universitas Jenderal Achmad Yani, Cimahi, Jawa Barat, \\ Indonesia \\ ${ }^{2}$ Bagian Ilmu Kesehatan Masyarakat Fakultas Kedokteran Universitas Jenderal Achmad Yani, \\ Cimahi, Jawa Barat, Indonesia \\ Email Korespondensi: jihanamaliadr@gmail.com
}

\begin{abstract}
ABSTRAK
Indonesia menempati peringkat ke-5 dalam daftar negara dengan angka kejadian stunting terbanyak di dunia. Dampak stunting salah satunya menurunnya perkembangan fungsi kognitif, sehingga berpengaruh terhadap kualitas anak Indonesia di masa yang akan datang. Salah satu upaya penanggulangan stunting, yang dilakukan Dinas Kesehatan Kabupaten Banyumas adalah dengan pemberian suplementasi zink selama 3 bulan dengan dosis $5 \mathrm{mg} /$ hari terhadap balita stunting usia 12-59 bulan. Zink merupakan mikromineral esensial sebagai kofaktor lebih dari 100 metaloenzim. Kekurangan asupan zink berpengaruh terhadap pertumbuhan. Tujuan penelitian ini untuk mengetahui pengaruh pemberian zink selama tiga bulan terhadap perubahan tinggi badan balita stunting di Puskesmas Cilongok I dan II Kabupaten Banyumas. Metode penelitian menggunakan rancangan observasional analitik dengan pendekatan kohort prospektif. Sampel penelitian diambil secara simple random sampling dan didapatkan responden sebanyak 38 orang yang memenuhi kriteria inklusi dan eksklusi. Berdasarkan wawancara kepada ibu balita stunting, didapatkan hasil kepatuhan pemberian zink adalah sebanyak 68,42\%. Berdasarkan Lembar Pemantauan Status Gizi Balita, didapatkan rerata perubahan tinggi badan (TB) yang terjadi setelah 3 bulan adalah $4,76 \mathrm{~cm}$. Hasil ini melebihi nilai rerata penambahan TB yang diharapkan, yaitu $3,75 \mathrm{~cm}$. Hasil analisis Chi square menunjukkan terdapat pengaruh pemberian zink selama 3 bulan terhadap perubahan tinggi badan balita stunting (nilai $\mathrm{p}<0,05$ ). Pemenuhan asupan zat gizi makro dan mikro, salah satunya zink berpengaruh terhadap perubahan tinggi badan anak.
\end{abstract}

Kata kunci : balita, stunting, zink 
Amalia, J : Suplementasi Zink Tiga Bulan Berpengaruh Pada...

\begin{abstract}
Indonesia is ranked the 5th in the chart of countries with the highest stunting prevalence in the world. One of the impacts of stunting is a decrease in the development of cognitive function, which will affect the quality of Indonesia's human resources in the future. One of the measures to overcome stunting implemented by the Health Service of Banyumas district is to administer zinc supplementation for 3 months with $5 \mathrm{mg} /$ day dose to toddler of 12-59 months age who suffered from stunting. Zinc is an essential micromineral as a cofactor of more than 100 metalloenzymes. Lack of zinc intake may disturb growth. The aim of this study was to identify the impact of zinc administration for 3 months on changes in height at the children with stunting at the Community Health Center in Cilongok one and Cilongok two in Banyumas district. The study method used analytic observational design with a prospective cohort approach. The study samples, 38 respondents meeting the inclusion criteria, were taken through simple random sampling. Based on the interview with the mothers of the children with stunting, it was found that the obedience of zinc administration was $68.42 \%$. Based on the Nutrition Status Monitoring Sheet for children, it was obtained that the average height change (Body Height) resulted after 3 months was $4.76 \mathrm{~cm}$. This result exceeded the average value of additional height gain, which was $3.75 \mathrm{~cm}$. The chi square analysis showed that there was an impact of 3-month zinc administration on the changes of body height of the children with stunting ( $p$ value <0,05). Fulfillment of macro and micro nutritional intake, one of which zinc, has an effect on changes in children's height.
\end{abstract}

Keywords: stunting, toddler, zinc

\section{PENDAHULUAN}

Stunting adalah keadaan ketika didapatkan tinggi badan seorang anak lebih pendek dibanding tinggi badan anak seusianya. Stunting terjadi akibat kekurangan gizi kronis yang terjadi saat anak dikandungan ibu dan pada masa awal kehidupan setelah lahir. Kondisi stunting didapatkan saat diukur panjang atau tinggi badan kurang dari -2 standar deviasi (SD) median standar pertumbuhan anak dari World Health Organization (WHO). Kondisi stunting berdampak buruk bagi anak, salah satunya adalah menurunkan perkembangan kognitif anak, sehingga dapat memengaruhi kualitas hidup anak tersebut di masa depan. Gizi menjadi faktor yang memengaruhi kesuksesan tumbuh kembang optimal bagi anak. Terpenuhinya kecukupan dan keseimbangan gizi seorang anak diperlukan dalam pertumbuhan dan perkembangan. Usia balita memiliki peran yang penting dalam pertumbuhan anak. Asupan zat gizi pada anak bawah lima tahun akan berpengaruh pada pertumbuhan dan perkembangan anak di masa depan. Masa periode emas tumbuh kembang balita terjadi sejak anak masih dalam kandungan hingga usia dua tahun atau yang disebut 
Amalia, J : Suplementasi Zink Tiga Bulan Berpengaruh Pada...

dengan "Seribu Hari Pertama Kehidupan (HPK) Anak”. Status gizi saat 1000 HPK akan berpengaruh terhadap kualitas anak. Kekurangan gizi yang kronis pada 1000 HPK mengakibatkan beberapa masalah, salah satunya, yaitu postur tubuh anak akan lebih pendek dari standar pertumbuhan. ${ }^{1-4}$

Pertumbuhan bayi dari lahir hingga usia dua tahun ditandai dengan pertumbuhan yang cepat, kemudian usia dua tahun sampai lima tahun menjadi lebih lambat. ${ }^{5}$ Hambatan pertumbuhan harus segera dikenali dan diintervensi sedini mungkin karena pada masa periode emas terjadi pertumbuhan yang sangat cepat baik secara fisik maupun pertumbuhan otak anak. ${ }^{1} \quad$ Upaya penanggulangan stunting oleh Pemerintah Indonesia dengan melakukan intervensi gizi spesifik dan sensitif. Intervensi gizi spesifik bagi stunting merupakan intervensi yang ditujukan secara langsung untuk anak, salah satu adalah dengan suplementasi zink. ${ }^{3}$ Pemberian suplemen zink dapat meningkatkan konsentrasi plasma Insulinlike Growth Factor I (IGF I) sehingga terjadi peningkatan kecepatan pertumbuhan. Insulin like Growth Factor I merupakan mediator hormon pertumbuhan. Kegagalan pertumbuhan dijumpai pada balita stunting dengan penurunan konsentrasi IGF I.
Menurunnya konsentrasi IGF I disebabkan tidak hanya karena kekurangan energi protein, tetapi juga kekurangan zink. $^{6}$ Manifestasi klinis anak yang kekurangan asupan zink yaitu menurunnya nafsu makan, kemampuan penyembuhan infeksi yang lama, menurunnya sistem imunitas tubuh, hingga menyebabkan kematian. ${ }^{7}$

Suplementasi zink secara bermakna memiliki hasil yang positif terhadap kenaikan berat, tinggi badan, dan dapat meningkatkan pertumbuhan linear pada balita stunting. ${ }^{6}$ Kusudaryati dkk. pada tahun 2017 melakukan penelitian mengenai pengaruh suplementasi zink terhadap perubahan indeks TB/U anak stunting pada usia 24-36 bulan. Hasil yang didapat suplementasi zink pada anak stunting berpengaruh terhadap perubahan skor $\mathrm{Z}$ tinggi badan berdasarkan usia (TB/U), asupan gizi dan kejadian infeksi. ${ }^{6}$ Abdollahi dkk. pada tahun 2019 melakukan penelitian mengenai efektivitas strategi suplementasi zink dalam mengurangi keterlambatan pertumbuhan dan hasil penelitiannya menunjukkan terdapat perubahan tinggi badan pada anak yang diberi suplementasi zink. ${ }^{8}$ Berdasarkan uraian di atas, peneliti tertarik untuk mengetahui pengaruh pemberian zink selama tiga bulan terhadap 
Amalia, J : Suplementasi Zink Tiga Bulan Berpengaruh Pada...

perubahan tinggi badan balita stunting di Puskesmas Cilongok di Kabupaten Banyumas. Dinas Kesehatan Kabupaten Banyumas memiliki program pemberian suplementasi zink terhadap balita usia 12-59 bulan stunting yang memiliki tinggi badan kurang dari -2 SD. ${ }^{3}$ Puskesmas Cilongok merupakan puskesmas dengan insidensi stunting tertinggi di Kecamatan Cilongok, Kabupaten Banyumas.

\section{BAHAN DAN METODE}

Penelitian bersifat observasional analitik menggunakan desain kohort retrospektif, yaitu penelitian yang dimulai dengan melakukan identifikasi faktor risiko terlebih dahulu, kemudian subjek diikuti secara prospektif selama periode tertentu untuk mencari ada atau tidaknya efek yang ditimbulkan oleh faktor risiko tersebut.

Subjek penelitian ini adalah balita stunting di Puskesmas Cilongok I dan II. Populasi penelitian ini, yaitu 60 orang balita stunting di Puskesmas Cilongok I dan II. Sampel diambil dari balita stunting usia 1259 bulan dengan tinggi badan kurang dari -2 standar deviasi yang berada di Puskesmas Cilongok I dan II dan telah menjalani suplementasi zink selama 3 bulan. Kriteria eksklusi penelitian ini adalah ibu balita stunting yang pendek, bayi dalam kondisi cacat, bayi lahir prematur (masa kehamilan <37 minggu) dan jika data pemantauan tinggi badan dan kepatuhan minum zink tidak lengkap. Responden yang memenuhi kriteria inklusi sebanyak 38 balita stunting dan ini sudah memenuhi jumlah minimal sampel yaitu 32 balita stunting. Seluruh balita yang memenuhi kriteria inklusi menjadi responden penelitian ini.

Instrumen penelitian berupa data rekam medis dari petugas gizi selama masa penelitian, lembar persetujuan (informed consent) yang didukung oleh lembar pemantauan status gizi balita stunting serta wawancara pada ibu balita stunting mengenai gambaran pemberian zink dengan tujuan memperoleh informasi cara pemberian zink pada balita stunting.

Tahap persiapan awal penelitian, yaitu dengan membuat proposal penelitian, penentuan tempat penelitian, dan peneliti melakukan pencarian data awal penelitian, yaitu data jumlah balita stunting di setiap puskesmas yang ada di Kabupaten Banyumas melalui Dinas Kesehatan Kabupaten Banyumas. Setelah mendapatkan data, peneliti menentukan tempat penelitian berdasarkan insidensi tertinggi dan setelah itu membuat surat permohonan izin untuk 
Amalia, J : Suplementasi Zink Tiga Bulan Berpengaruh Pada...

melakukan penelitian di Puskesmas yang terpilih. Tahap berikutnya, yaitu pengambilan sampel penelitian adalah orang tua dari balita akan diberikan penjelasan mengenai penelitian dan informed consent untuk mengikuti penelitian, selanjutnya dilihat penilaian stunting berdasarkan hasil data rekapitulasi pengukuran tinggi badan (untuk anak diatas usia 24 bulan diukur telentang, maka hasil pengukurannya dikoreksi dengan mengurangkan $0,7 \mathrm{~cm}$ ) yang dilakukan oleh petugas gizi, kemudian diukur tinggi badan balita tersebut setelah 3 bulan, apakah perubahan tinggi badan balita stunting termasuk kategori tercapai atau tidak tercapai. Perubahan tinggi badan disebut tercapai jika terdapat kenaikan tinggi badan minimal sebesar $3,75 \mathrm{~cm}$ dalam 3 bulan. Tahap akhir pembuatan laporan dengan mengolah data hasil penelitian dan dianalisis menggunakan analisis univariat dan bivariat menggunakan chi-square.
Penelitian telah mendapat persetujuan etik dengan nomor 050/UM1.11/2020 pada 26 November 2020 dari Komisi Etik Penelitian Kesehatan Fakultas Kedokteran Universitas Jenderal Achmad Yani.

\section{HASIL DAN PEMBAHASAN}

Penelitian telah dilakukan di Puskesmas Cilongok I dan II pada bulan November 2020-Januari 2021. Balita stunting yang memenuhi kriteria inklusi penelitian serta bersedia mengisi informed consent dan kuesioner Lembar Pemantauan Status Gizi Balita Stunting (TB/U) sebanyak 38 balita dari total responden sebanyak 60 balita stunting. Terdapat 22 balita stunting yang tidak masuk dalam kriteria inklusi, paling banyak terjadi karena bayi sulit dikendalikan saat pengukuran ataupun tidak datang saat pengukuran. Hasil penelitian yang diperoleh dapat dilihat sebagai berikut.

Tabel 1 Karakteristik balita berdasarkan jenis kelamin dan tinggi badan

\begin{tabular}{llll}
\hline & & Frekuensi & Persentase \\
\hline Jenis kelamin & Laki-laki & 19 & $50,00 \%$ \\
& Perempuan & 19 & $50,00 \%$ \\
Tinggi badan & Pendek & 20 & $52,6 \%$ \\
& Sangat pendek & 18 & $47,37 \%$ \\
\hline
\end{tabular}


Amalia, J : Suplementasi Zink Tiga Bulan Berpengaruh Pada...

Tabel 1 menggambarkan karakteristik balita stunting berdasarkan jenis kelamin dan tinggi badan. Hasil didapatkan bahwa seluruh balita yang mengalami stunting sebanyak 19 balita atau $50 \%$ berjenis kelamin laki-laki dan perempuan. Hasil penelitian berdasarkan tinggi badan didapatkan mayoritas balita sebanyak 20 orang atau $52,63 \%$ adalah balita yang memiliki tinggi badan dengan status kategori pendek. Hasil penelitian ini tidak sejalan Setiawan pada tahun 2018 yang menyatakan bahwa $52,2 \%$ balita stunting berjenis kelamin laki-laki dari total 67 balita stunting. ${ }^{9}$ Hasil penelitian mengenai klasifikasi tinggi badan sesuai dengan data RISKESDAS tahun 2018 menunjukkan bahwa prevalensi balita pendek lebih tinggi $7,8 \%$ dibanding sangat pendek. ${ }^{10}$

Kepatuhan pemberian zink akan didapatkan kategori patuh jika diminumkan $5 \mathrm{mg} /$ hari tanpa ada yang terlewat atau 2 botol sirop zink habis dalam 90 hari dan tidak patuh didapatkan diminumkan $5 \mathrm{mg} /$ hari ada hari terlewat atau 2 botol sirop zink habis sebelum/melebihi 90 hari. ${ }^{3}$ Kepatuhan pemberian zink pada balita stunting dalam penelitian ini dapat dilihat pada Gambar 1.

\section{Kepatuhan Pemberian Zink}

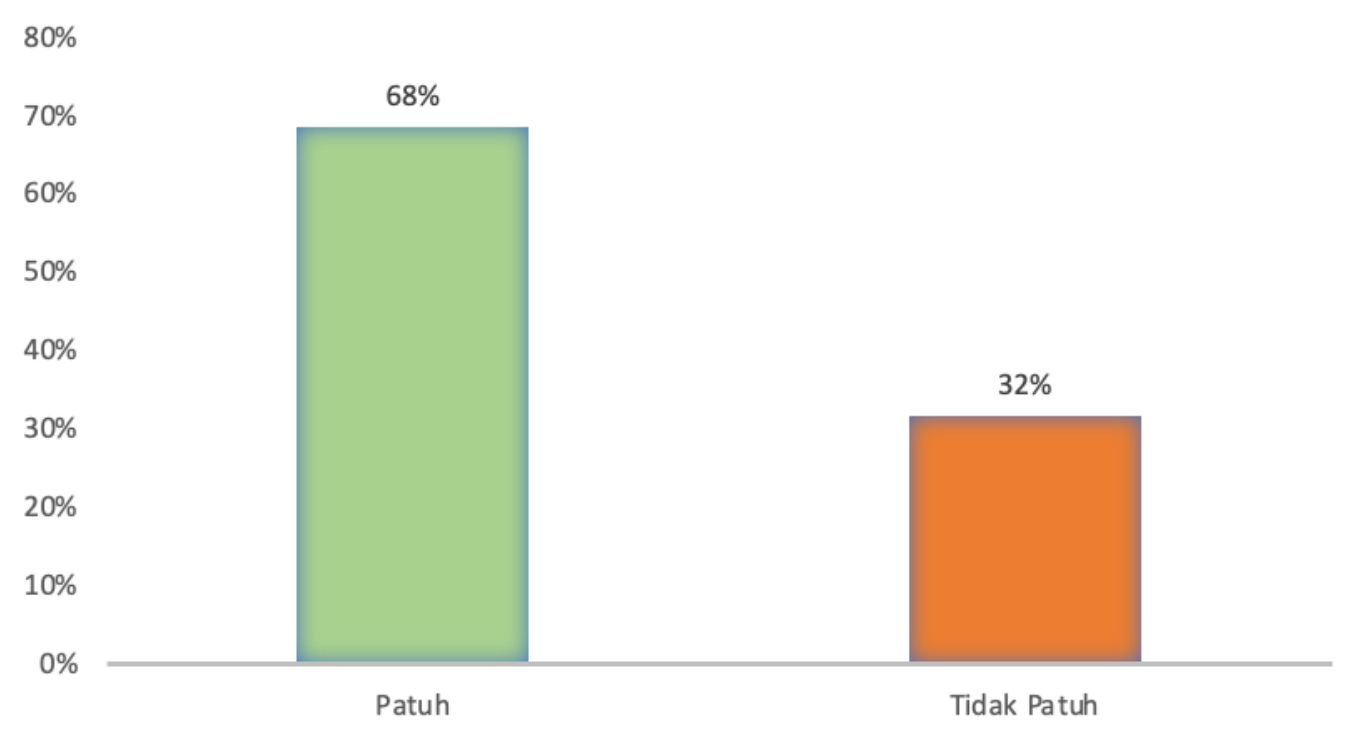

Gambar 1 Gambaran kepatuhan pemberian zink.

Hasil penelitian menunjukkan bahwa sebanyak 26 balita atau $68,42 \%$ balita termasuk kategori patuh. Balita yang dikategorikan patuh sudah sesuai dengan petunjuk Kemenkes mengenai Angka Kecukupan Gizi (AKG) untuk zink yang 
Amalia, J : Suplementasi Zink Tiga Bulan Berpengaruh Pada...

dianjurkan pada balita Indonesia untuk usia 1-3 tahun sebanyak $4 \mathrm{mg} / \mathrm{hari}$ dan usia 4-6 tahun sebanyak $5 \mathrm{mg} /$ hari. $^{3}$

Faktor-faktor yang berhubungan dengan kepatuhan, yaitu dukungan keluarga, motivasi ibu, sikap ibu, dan tingkat pengetahuan tentang tatalaksana. ${ }^{11}$ Angka kepatuhan yang tinggi di Puskesmas Cilongok I dan II berdasarkan hasil wawancara, yaitu karena jarak rumah yang dekat terhadap pelayanan kesehatan, dan adanya evaluasi mengenai pemberian zink yang dilakukan setiap hari, yaitu dengan cara pengisian kuesioner yang harus diisi setelah ibu setiap melakukan pemberian zink serta adanya evaluasi setiap satu bulan sekali oleh petugas gizi untuk memantau tinggi badan anak. Pemberian zink secara gratis yang menjadi program pemerintah juga menjadi salah satu faktor kesuksesan tercapainya angka kepatuhan yang tinggi, karena ibu tidak perlu mengeluarkan biaya untuk memperbaiki status gizi anaknya.

Berdasarkan hasil wawancara, balita stunting yang termasuk dalam kategori tidak patuh paling banyak karena kurangnya edukasi mengenai manfaat pemberian zink, beberapa ibu beranggapan bahwa pemberian zink dilakukan untuk kasus diare, serta persepsi ibu mengenai sirop dua botol "yang penting habis", seharusnya pemberian dilakukan setiap hari dengan dosis $5 \mathrm{mg}$ yang akan habis dalam waktu 90 hari. ${ }^{12}$ Gambaran perubahan tinggi badan balita stunting selama tiga bulan setelah pemberian suplementasi zink dapat dilihat pada Tabel 2 memperlihatkan perubahan tinggi badan balita stunting selama tiga bulan setelah pemberian suplementasi zink.

Tabel 2 Gambaran perubahan tinggi badan balita stunting selama tiga bulan setelah pemberian suplementasi zink

\begin{tabular}{cccccc}
\hline Rerata & SD & Median & Modus & Minimum & Maksimum \\
\hline 4,76 & 1,90 & 4,33 & 4,20 & 1 & 10 \\
\hline
\end{tabular}

Hasil penelitian menunjukkan bahwa rerata perubahan tinggi badan balita stunting sebesar 4,76 cm. Terdapat perbedaan dengan penelitian Kusudaryati dkk. pada tahun 2016 bahwa pemberian suplementasi zink pada balita stunting sebanyak 4 mg selama 9 kali, didapatkan hasil peningkatan tinggi badan dengan rerata $2,8 \mathrm{~cm}^{6}$ Terdapat rerata 
Amalia, J : Suplementasi Zink Tiga Bulan Berpengaruh Pada...

perubahan tinggi badan didapatkan karena balita stunting di Puskesmas Cilongok diberikan zink setiap hari selama tiga bulan, dengan pemberian dosis sebanyak $5 \mathrm{mg}$. Idealnya pemberian zink sesuai dengan Kemenkes bahwa Angka Kecukupan Gizi (AKG) zink untuk balita usia 1-3 tahun sebanyak 4mg/hari, dan usia 4-6 tahun sebanyak $5 \mathrm{mg}$ /hari. Pemberian suplementasi zink selama 14 hari dapat meningkatkan nafsu makan anak tetapi tidak memberikan perubahan TB/U. Kejadian stunting sangat berkaitan dengan rendahnya asupan makanan, terutama bahan makanan karbohidrat, protein, dan zink. Asupan zink yang rendah mengakibatkan selera makan anak menurun. Turunnya selera makan akibat konsentrasi zink yang berada di saliva (enzyme alpha amylase) rendah lalu mengakibatkan penurunan selera makan, yang mempengaruhi tingkat kecukupan energi. ${ }^{13}$ Tabel 3 memperlihatkan pengaruh pemberian zink selama tiga bulan terhadap perubahan tinggi badan balita stunting.

Tabel 3 Pengaruh pemberian zink selama tiga bulan terhadap perubahan tinggi badan

\begin{tabular}{|c|c|c|c|c|c|c|c|c|}
\hline & & \multicolumn{4}{|c|}{ Perubahan Tinggi Badan } & \multirow{2}{*}{\multicolumn{2}{|c|}{ Total }} & \multirow{3}{*}{ Nilai P } \\
\hline & & \multicolumn{2}{|c|}{ Tercapai } & \multicolumn{2}{|c|}{ Tidak Tercapai } & & & \\
\hline & & $\mathbf{F}$ & $\%$ & $\mathbf{F}$ & $\%$ & $\mathbf{F}$ & $\%$ & \\
\hline \multirow{3}{*}{$\begin{array}{l}\text { Pemberian } \\
\text { Zink }\end{array}$} & Patuh & 23 & 60,53 & 3 & 7,89 & 26 & 68,42 & \multirow{3}{*}{0,000} \\
\hline & Tidak Patuh & 3 & 7,89 & 9 & 23,68 & 12 & 31,58 & \\
\hline & Total & 26 & 68,42 & 12 & 31,58 & 38 & 100,00 & \\
\hline
\end{tabular}

Berdasarkan hasil tersebut, didapatkan nilai $\mathrm{P}$ dari pengujian Chi-square sebesar 0,000. Nilai $\mathrm{P}(0,000)<\alpha(0,05)$ menyatakan $\mathrm{H}_{0}$ ditolak dan $\mathrm{H}_{1}$ diterima, artinya terdapat pengaruh antara pemberian zink selama tiga bulan terhadap perubahan tinggi badan. Hasil penelitian ini sesuai dengan Liu E dkk. pada tahun 2018 menyatakan bahwa pemberian suplementasi zink secara dini (saat sudah lahir) memberikan hasil peningkatan secara spesifik pada pertumbuhan. ${ }^{14}$ Data Kemenkes mengenai perubahan tinggi badan yang ideal tanpa suplementasi zink, yaitu $1,25 \mathrm{~cm}$ tiap bulan, dalam waktu tiga bulan minimal terjadi peningkatan tinggi badan 
Amalia, J : Suplementasi Zink Tiga Bulan Berpengaruh Pada...

sebanyak $\quad 3,75 \quad \mathrm{~cm} .{ }^{15} \quad$ Pemberian suplementasi zink dapat menurunkan kejadian anoreksia, demam, pilek, dan rasa mual pada anak stunting. Defisiensi zink akan menyebabkan gangguan pada reseptor GH dan produksi GH yang menjadi resistan. Sekresi GH menyebabkan terjadinya sintesis IGF-I dan glikogen di hepar, sintesis protein di otot meningkat, lipolisis di jaringan adiposa meningkat, dan merangsang pertumbuhan tulang. IGF-I berikatan dengan reseptor IGF yang kemudian akan mengaktivasi IRS-1/2. Fosforilasi IRS1/2 akan menginisiasi mitogenactivated protein kinase akan menginduksi faktor transkripsi dan memicu poliferasi sel. ${ }^{16-19}$

Penelitian ini sejalan dengan penelitian Isyraqi $\mathrm{G}$ dan Candra $\mathrm{A}$ di Semarang pada tahun 2016 pada balita usia 3-5 tahun. Pemberian dosis suplementasi zink yang diberikan, yaitu $10 \mathrm{mg} /$ hari selama tiga bulan. responden diambil setelah melewati tahap screening akan diacak (random) ke dalam empat kelompok. Subjek dalam penelitian ini adalah 36 orang atau sembilan orang per kelompok. Konsumsi zink dilakukan setiap pagi hari sebelum sarapan. Pembagian menjadi 4 kelompok. Kelompok satu, yaitu kontrol hanya diberi sirop multivitamin yang tidak mengandung zink dan Fe. Kelompok dua diberika sirop suplemen dengan dosis $10 \mathrm{mg} / \mathrm{hari}$. Kelompok tiga diberikan suplemen zat besi dalam bentuk sirop dengan dosis 7,5 $\mathrm{mg} /$ hari. Kelompok empat diberikan seng dan zat besi dalam kemasan sirop dengan dosis seng $10 \mathrm{mg} / \mathrm{hari}$ dan zat besi 7,5 $\mathrm{mg} /$ hari. Kesimpulannya ada pengaruh signifikan terhadap tinggi badan subjek di empat kelompok penelitian $(p<0,05)$. Terdapat persamaan dengan penelitian ini dikarenakan sampel pada penelitian merupakan balita, faktor usia berpengaruh karena pada balita terjadi proses pertumbuhan secara cepat. ${ }^{20-23}$

Hasil penelitian ini berbeda dengan penelitian yang dilakukan oleh Ahmad F dkk. di SDN 13 Batang Anai, Padang pada tahun 2018 bahwa dari 33 orang dengan usia 7-9 tahun responden yang mengonsumsi zink terdiri dari dua kelompok, kelompok satu (teratur mengonsumsi zink) sebanyak empat belas orang dan kelompok dua (tidak teratur mengonsumsi zink). Kesimpulan tidak terdapat perbedaan bermakna tinggi badan pada kelompok satu dan dua. Terdapat perbedaan pada penelitian ini dikarenakan faktor usia, penelitian ini bukan dilakukan secara dini saat terjadi periode emas, saat terjadi pertumbuhan secara cepat. Faktor 
Amalia, J : Suplementasi Zink Tiga Bulan Berpengaruh Pada...

penyebab perbedaan kemungkinan dari dosis zink, pendeknya periode suplementasi, atau adanya defisiensi zat gizi selain zink. ${ }^{7,24}$

Pemberian suplementasi sesegera mungkin dapat memberikan hasil yang maksimal, terlebih saat masih balita. Periode emas merupakan periode saat dalam kandungan ibu sampai umur dua tahun atau dikenal dengan istilah "Seribu Hari Pertama Kehidupan Anak”. Status gizi pada 1000 HPK akan berpengaruh terhadap kualitas anak karena pada awal kehidupan terjadi pertumbuhan yang sangat cepat baik fisik maupun otak. Kekurangan gizi secara kronis menyebabkan masalah gagal tumbuh sehingga anak menjadi lebih pendek dari standar pertumbuhan. Zink berperan mengaktifkan hormon pertumbuhan yang menyebabkan terjadinya sintesis IGF-I, lalu IGF-I akan berikatan dengan reseptor IGF yang membuat aktivasi IRS-1/2, dan terjadi fosforilasi IRS-1/2. Fosforilasi IRS-1/2 akan menginisiasi mitogenactivated protein kinase, lalu memicu proliferasi dan diferensiasi kondrosit di lempeng epifisis, yang kemudian akan merangsang pertumbuhan tulang dan meningkatkan tinggi badan seseorang. ${ }^{16,25,26}$

\section{KESIMPULAN}

Berdasarkan hasil penelitian ini didapatkan mayoritas balita stunting yang mendapat pemberian zink selama tiga bulan berada dalam kategori patuh, yaitu sebanyak 26 orang dari 38 responden atau $68,42 \%$. Rerata perubahan tinggi badan balita stunting sebesar $4,76 \mathrm{~cm}$ dan telah melebihi target, yaitu $3,75 \mathrm{~cm}$. Perubahan tinggi badan paling banyak tercapai dari kategori patuh, yaitu sebesar 60,53\%. Terdapat pengaruh pemberian zink selama tiga bulan terhadap perubahan tinggi badan balita stunting di Puskesmas Cilongok di Kabupaten Banyumas.

\section{KONFLIK KEPENTINGAN}

Dengan ini kami menyatakan bahwa tidak terdapat konflik kepentingan dalam artikel ilmiah yang kami tulis.

\section{UCAPAN TERIMA KASIH}

Ucapan terima kasih kami sampaikan kepada para profesional yang telah membantu penelitian dan penyusunan artikel penelitian diantaranya Dinas Kesehatan Kabupaten Banyumas, Kepala Puskesmas Cilongok I dan II beserta staf dan kader kesehatan. 
Amalia, J : Suplementasi Zink Tiga Bulan Berpengaruh Pada...

\section{DAFTAR PUSTAKA}

1. Pusat Data dan Informasi Kementerian Kesehatan RI (InfoDatin). Situasi Balita Pendek (Stunting) di Indonesia. InfoDatin. Jakarta. 2018.

2. Tim Nasional Percepatan Penanggulangan Kemiskinan (TNP2K). 100 Kabupaten/Kota Prioritas Untuk Intervensi Anak Kerdil (Stunting). TNP2K. Jakarta. 2017.

3. Nugroho A. Petunjuk Teknis Program Peningkatan Status Gizi Masyarakat Dinas Kesehatan Kabupaten Banyumas Tahun 2020. https://www.scribd.com/document/4139 29502/JUKNIS-Suplementasi-Zn-PDF. 2020. [accessed Maret 5th 2020].

4. Teja M. Stunting Balita Indonesia dan Penanggulangannya. Pusat Penelitian Badan Keahlian DPR RI, XI. 2019:1318.

5. Djauhari T. Gizi dan 1000 HPK. Saintika Medika: Jurnal Ilmu Kesehatan dan Kedokteran Keluarga. 2017;13(2) :125-33.

6. Kusudaryati DPD, Muis SF, Widajanti L. Pengaruh Suplementasi Zn Terhadap Perubahan Indeks TB/U Anak Stunting Usia 24-36 Bulan. Jurnal Gizi Indonesia 2017; 5(2): 98-104.
7. Muhammad F, Nurhajjah S, Revilla G. Pengaruh Pemberian Suplemen Zink Terhadap Status Gizi Anak Sekolah Dasar. Jurnal Kesehatan Andalas 2018; 7(2): 285-90.

8. Abdollahi M, Ajami M, Abdollahi Z, Klantari N, Houshiarrad A, Fozuni F,et al. Zinc supplementation is an effective and feasible strategy to prevent growth retardation in 6 to 24 . month children: A pragmatic double blind, randomized trial. Heliyon 2019;5(11): 1-7.

9. Setiawan E, Machmud R, Masrul M. Faktor-Faktor yang Berhubungan dengan Kejadian Stunting pada Anak Usia 24-59 Bulan di Wilayah Kerja Puskesmas Andalas Kecamatan Padang Timur Kota Padang Tahun 2018. Jurnal Kesehatan Andalas. 2018 Jun 10;7(2):275-84.

10. Riset Kesehatan Dasar. Hasil Utama Rikesdas 2018. Rikesdas. Jakarta. 2018.Riset Kesehatan Dasar. Hasil Utama Rikesdas 2018. Rikesdas. Jakarta. 2018.

11. Didit D. Gizi Dalam Daur Kehidupan. KEMENKES RI. Jakarta. 2017.

12. Senewe MS, Rompas S, Lolong J. Analisis faktor-faktor yang berhubungan 
Amalia, J : Suplementasi Zink Tiga Bulan Berpengaruh Pada...

dengan kepatuhan ibu dalam pemberian imunisasi dasar di Puskesmas Tongkaina Kecamatan Bunaken Kotamadya Manado. Jurnal Keperawatan. 2017 Jan 19;5(1).

13. Subandra Y, Zuhairini Y, Djain J. Hubungan Pemberian Asi Ekslusif dan Makanan Pendamping ASI Terhadap Balita Pendek Usia 2 sampai 5 tahun di Kecamatan Jatinangor. JSK 2018; 3(3): 142-48.

14. Liu E, Pimpin L, Shulkin M. Effect of Zinc Supplementation on Growth Outcomes in Children under 5 Years of Age. MDPI 2018. 3-20.

15. Setiyani A, Sukesi A, Esyuananik. Asuhan Kebidanan Neonatus, Bayi, Balita, dan Anak Pra Sekolah. Kementerian Kesehatan Republik Indonesia. Jakarta. 2016: 14-16.

16. Nurmadilla N, Marisa. Potensi Zink Dalam Tatalaksana Berbagai Penyakit. Cermin Dunia Kedokteran. 2018:21418.

17. Ghazian MI, Candra A. Pengaruh Suplementasi Seng dan Zat Besi Terhadap Tinggi Badan Balita Usia 3-5 Tahun di Kota Semarang. Journal Of Nutrition College 2016; 5(4): 491-98.
18. Wahyulian A, Rasyid R, Mariko R. Hubungan Kadar Zink Dan Kenaikan Berat Badan Ibu Hamil Dengan Berat Badan Bayi Lahir Di RSUD Curup Kabupaten Rejang Lebong Prov Bengkulu. Majalah Kedokteran Andalas; 2(42): 56-61.

19. Sari AN, Maryanto S, Purbowati. Hubungan Asupan Zink, Zat Besi, dan Vitamin C dengan Kejadian Gizi Kurang Pada Anak Usia 6-24 Bulan Di Desa Leyangan, Kecamatan Ungaran Timur Kabupaten Semarang. Jurnal Gizi dan Kesehatan 2020; 12(27): 11-20.

20. Dewi EK, Nindya TS. Hubungan Tingkat Kecukupan Zat Besi Dan Seng Dengan Kejadian Stunting Pada Balita 6-23 Bulan. Amerta Nutrition. 2017: 27;1(4):361-8.

21. Pramono A, Panunggal B, Anggraeni N. Asupan Seng Kadar Serum Seng Dan Stunting Pada Anak Sekolah Di Pesisir Semarang. Jurnal Gizi Pangan 2016; 11(1): 19-26.

22. Aridiyah FO, Rohmawati N, Ririanty M. Faktor-faktor yang Mempengaruhi Kejadian Stunting pada Anak Balita di Wilayah Pedesaan dan Perkotaan. eJurnal Pustaka Kesehatan 2015; 3(1): 163-70. 
Amalia, J : Suplementasi Zink Tiga Bulan Berpengaruh Pada...

23. Mills, F Collin. Zinc in human biology. London 1989. 351.

24. Dwi F, Alam N, Misnaniarti. Hubungan Antara Pola Asuh Keluarga Dengan Kejadian Balita Stunting Pada Keluarga Miskin Di Palembang. Jurnal Epidemiologi Kesehatan Komunitas 2020; 5(1): 15-22.

25. Subandra Y, Zuhairini Y, Djain J. Hubungan Pemberian Asi Ekslusif dan Makanan Pendamping ASI Terhadap Balita Pendek Usia 2 sampai 5 tahun di
Kecamatan Jatinangor. JSK 2018; 3(3): $142-48$.

26. Rachmi CN, Esthetika Wulandari, Harry Kurniawan, Luh Ade, Rinaldi Ridwan, Tulus Ciptadi Akib. Aksi Bergizi. 2019:5-9 